\title{
Fasıl tarihinde dönüșüm ve direklerarası fasıl refakat gelenekleri
}

\author{
Öğr. Gör. Dr. Bekir Șahin Baloğlu*
}

Arș. Gör. Bedirhan Büyükduman**

*Sorumlu yazar, Yıldız Teknik Üniversitesi, Sanat ve Tasarım Fakültesi, Müzik ve Sahne Sanatları Bölümü, Yıldız Teknik Üniversitesi, Sanat ve Tasarım Fakültesi, Davutpașa Kampüsü, İstanbul, Türkiye, e-Mail: bbaloglu@yildiz.edu.tr, https://orcid.org/0000-0002-3189-0371

** İstanbul Sabahattin Zaim Üniversitesi, Müzik Öğretmenliği Bölümü, İstanbul Sabahattin Zaim Üniversitesi, Müzik Öğretmenliği Bölümü, Halkalı Merkez Kampüsü, Halkalı, 34303, Küçükçekmece, İstanbul, Türkiye, e-Mail: bedirhan.buyukduman@izu.edu.tr, https://orcid.org/0000-0002-6975-0470

DOI 10.12975/rastmd.2021925 Submitted August 15, 2021 Accepted October 5, 2021

\begin{abstract}
Özet
Osmanlı'nın son zamanlarından günümüze kadar uzanan Türk müziği icra geleneklerinden "fasıl" özel bir yer teșkil eder. Aynı makamda birkaç eserin ağırdan hareketliye belli bir dizilimle icra edilmesi özel anlamının yanı sıra fasıl, herhangi bir musiki icrasını açıklamak için de kullanıla gelmiș, geniş bir anlama malik olmuștur. Ondokuzuncu yüzyıl bașında beliren "klasik fasıl” ile aynı yüzyılın sonundaki "direklerarası fasıl"ın içerik ve sunum açısından farkları bulunması, veriler doğrultusunda bu dramatik dönüșümün de açıklanmasını gerektirmektedir. Repertuar, icracılar ve bu kültür içinde olușan icra üslubu, yaklașık son yüz yıldır yaygın olarak kullanılan Avrupa notasının dikte ettiği yalınlıktan çok uzak bir konumdadır. Fasılda kullanılan ritm sazların velveleli üslubu ile mızraplı sazların uzun seslerde yaptıkları ilave notaların birbiriyle ilgisi olduğu açıktır. Bu çalıșmada, fasıl üsluplarındaki dönüșümün tarihsel izleri sürülecek ve direklerarası fasıl geleneğinde mızraplı ve ritm sazların fasıl müziğine etkileri irdelenecektir.
\end{abstract}

\section{Anahtar Kelimeler}

fasıl, icra nota farklılığı, mızraplı sazlar, refakat, ağır aksak

\section{Giriș}

Türk müziği, sözü uçucu bilip yazıyı yerine koyduğundan beri musikinin ve musiki kültürünün kavrayıșındaki muğlaklık süregider. Hoca, üstad, virtüöz yani otorite; talebe, kursiyer yani acemi; bunun da ötesinde bilginin konusu, hududu ve tanımı tartıșmalı bir haldedir. Yeni kavramlar eski kavramların eșliğinde hayata eklemlendiği için kargaşa olağandır. Bu noktada eskinin ya da yeninin tarafında olmaktan öte problemin açıkça ortaya konulmasına ihtiyaç vardır.

Batı ile birlikte yașamak yerine Batılılașmak zorunda olan Osmanlı'da, bu yeni yașam biçimini kabulleniş alt sınıf- ta ağır bir tempoda gerçekleșirken üst sınıf, yenilikleri daha hızlı bir șekilde karșilyyordu. Bu sebepledir ki Türk Batılılașma tarihi büyük oranda üst sınıftaki hareketliliğin tarihidir. Bununla birlikte alt sınıfın beğenilerine ilișkin malumatımız hiç yok değildir ancak bunlar yeterli olmadığı gibi kolayca istifade edilebilecek sistemli bir tasniften de -șimdilik- yoksundur. Toplumsal kabullenișin siyasî derinliği bir yana müzikte, özellikle de fasıl türünde görünen sonuçlar, İmparatorluğun son yüzyılının kısa bir özetini yansıtır. Zira bu fasıllar, yeni üst ve alt sınıfın kesiștiği ve buluștuğu mekanlarda, birleșen bir müzik beğenisi sembolüdür. 
Çalıșmada, fasıl ve onu barındıran toplumsal yapıdaki tarihsel dönüșümün izleri sürülecektir. Ayrıca üslup farkı nota üzerinde belirtilmeyen bir eserin, direklerarası $^{1}$ fasıl üslubunda icra edilirken enstrümanlarda dikkat edilen hususlar uygulamadaki örnekleri üzerinden gösterilecektir.

Canlı ve neșeli bir tarz olan direklerarasi fasil icrasinda klarnet, keman, yaylı tanbur gibi uzun sesli çalgıların melodinin köșe bașı olan bir tek sesi uzunca tınlatarak bıraktığı canlılık etkisi yahut nağme iskeletinin üst ve alt bölgelerinde geleneksel motiflerle yaptığı yaratıcı süslemeler, bu sazların yapısının direklerarası fasılda dikkat çeken hususiyetlerindendir. Lakin direklerarası fasılın dinamik yönünü en belirgin șekilde gösterenler tef ile darbuka gibi ritm ve ud ile kanun gibi mızraplı çalgılardır. Direklerarası faslı, çıkan girift sonuca binaen bir bütün olarak değerlendirdiğimiz için buna etki eden her enstrüman ve fasıl içinde yarattıkları canlılık teknikleri çalıșmamızın menzilinde yer almaktadır.

\section{Fasl-1 Tarih}

19. yüzyılda, sanatın herkesçe ulaşılabilir olması yönündeki anlayıșla birlikte Türk müziği de demokratlașmaya bașlamış; böylelikle genel tarih, ilgi alanını aristokrat sınıfının tercihlerinden geniș halk kitlelerinin tercihlerine doğru çevirmiștir. Bu konuda en büyük etken șüphesiz, geniş kitlelere müziği

1 İstanbul'da Vezneciler ve Şehzadebașı arasındaki caddenin bir kısmı Osmanlı döneminde Direklerarası olarak anılırdı. Bu cadde o dönemde ìstanbul'un en önemli eğlence, kültür ve sanat merkezlerinden birisi olarak kabul görmüștür. Kahvehaneleriyle meșhur Direklerarası, özellikle Ramazan aylarındaki müzikli eğlenceleriyle halkın vazgeçilmez uğrak bir yeri olmuştur. Detaylı bilgi için bkz. Bekir Tosun, "Direklerarası", içinde DIA, İstanbul: Türkiye Diyanet Vakfı Yayınları, 1994, s. 367-368. ileten ses kayıt teknolojilerindeki gelișmelerdir. Meclislerin veya toplu icra șekillerinin toplumun her tabakasında olabileceği tahmin edilse de tarihsel seyri belgelerle görülebilen meclisler, saray gibi üst kültürün yahut tekke gibi sinıflar üzerinde (ya da alt ve üst sinıflar arasında aracı) kurumların meclisleridir. Repertuar ve tavır açısından farklılıklarından ötürü bu noktada evvela saray musiki meclisleri üzerinde durmak yerinde olacaktır.

Osmanlı'da musiki meclislerindeki tertibin genel adı olan fasıl, 16. yüzyıldan beri kullanıldığı anlașılan bir kavram olarak tebarüz eder. Fasıl, icranın yapıldığı ân'ı tarif ettiği gibi bir makamın genișleme ve çeșitleme yollarını göstermek üzere bestelenen bir dizi müzik eserinin de adıdır. Peșrev, kâr, beste, ağır semai, yürük semai ve saz semaisi gibi formlardan oluşan fasıl, bugün klasik takım yahut klasik fasıl ismiyle bilinen III. Selim dönemine ait fasıldır. Türk makam müziğinin bel kemiğini olușturan bu klasik formatın ne zaman ve hangi süreçlerden geçerek bu șekli aldığı maalesef bilinmemektedir. Musikiyi himaye eden sarayın ve en büyük patronu olan padișah makamının, șüphesiz, bu meclislerin devamlılığındaki rolü büyüktür. Osmanlı'dan evvel, fasıl benzeri meclislerin Abbasi ve İran gibi saray kültürlerinde de olduğu bilinmektedir. Bahse konu olan çağlarda kaleme alınmıș s1nırl sayıdaki musiki risalelerini inceleyerek faslın tarihsel süreci hakkında kronolojik bir okuma yapan Eugenia Popescu-Judetz'in tespitleri her ne kadar kesin yargılar içermese de șüphesiz bu etkileșimi açıklayıcı en makul hipotezlerdir. 15. yüzyıl kaynaklarından referansla hareket eden Judetz'e göre Türk, İran ve Arap kültürlerinde fasıl benzeri 
tecrübeler nevbet ${ }^{2}$ adıyla yașıyordu ve fasıl terimi muhtemelen Osmanlı'da ilk kez 16. yüzyılda kullanılmaya bașlandı. Judetz, 17. yüzyılda Osmanlı saray musikisi repertuar seçkisi mahiyetindeki Ali Ufkî'nin (Saz ü Söz) ve Kantemiroğlu'nun (Kitâbü iltmi'l-mûsikî alâ vechi'l-hurûfât) mecmualarının içerdiği fasıllar; Hafız Post ve Evliya Çelebi'nin açıklayıcı metinleri üzerinden örnekler ve detaylarla kompakt bir fasıl tarihi ortaya koyar. ${ }^{3}$ Ancak, açıklanamayan tek șey icra üslubundaki ve içeriğindeki dönüșümdür. Zira söz konusu dönemdeki kavl, tasnif, nakș, savt, semai, murabba gibi formlar ve bunların gerektirdiği icra üslubu klasik takım içinde bahsedilen formlar ve icra üslubundan çok bașkadır. İçerikteki bu dramatik değișimi gösterecek kaynaklar olmadığı için tarihsel okumalar, yalnızca mevcudun tespiti ve șerhinden öteye gidemeyecektir. Dönüşümün ilișkilendirilebileceği en akla uygun çözüm siyasi konjonktürdeki değişimdir. Devlet politikalarının farklı cenahlara yönelișine bağlı olarak kitlesel hareketliliğin çeşitlenmesi, fonksiyonunu sabit bırakmak suretiyle müziğin içeriğini de etkilemiș olmalıdır. Judetz'in $(1999,786-87)$ bu konudaki açıklaması șöyledir:

"Fasıl, kavramsal olarak bir değișikliğe uğramamasına karșın klasik müziğin icra biçimi, müzik kültüründeki modernleșme ve Batılılașmadan

2 Eski bir Türk geleneği olarak nevbet, ilk olarak Büyük Selçuklular döneminde karșımıza çıkmaktadır. Hükümdârın hâkimiyet sembollerinden biri olarak kabul gören nevbet, Türklerin İslâmiyet'i kabulüyle Türkİslâm devletlerinin bir töresi hâlini alır. "Askerî müzik topluluğunun saray veya otağı önünde davul vurarak icra ettiği müzik" anlamında da kullanılan nevbet geleneği, Osmanlı Devleti'nde mehterhâne bünyesinde devam ettirilmiştir. Detaylı bilgi için bkz.: Timur Vural, Türklerde Askerî Müzik Geleneği Tuğ, Nevbet, Mehter, Konya: Cizgi Kitabevi Yayınları, 2013.

3 Detaylı bilgi için bkz.: Eugenia Popescu-Judetz, "Osmanlı'da Fasıl", içinde OSMANLI, c. 10, Ankara: Yeni Türkiye Yayınları, 1999. etkilenmiștir. Batılı enstrümanların benimsenmesi ve teorik fikirler bir yere kadar kompozisyonun içeriğini ve müzikal düzenlemeleri etkisi altına almıștır. Sanat müziği konserinin tiyatro sahnesinde sunulması icracılar ile dinleyici arasındaki ilișkiyi farklı kılmıștır. Öte yandan faslın semantiklerinden farklı kollar olușmuștur. Fasıl metinleri ve müzik notaları sanat müziğinin eğlence müziği alanında geniş bir biçimde yayılmasına yol açmıștır."

Hanedan üyesi ve padișah namzeti bir șehzadenin Avrupa'daki gelișmeleri takip etmesi, Fransız sarayı ile mektuplaşması muhakkak ki 15 . veya 16 . yüzyıldaki bir saray mensubu için düșünülemezdi. Ancak III. Selim'in bütün bunları ve fazlasını gerçekleștirmesi Avrupa toplumundaki siyasal, toplumsal, teknolojik gelișmelerin etkilerinin 18. yüzyıl sonlarında artık sarayın içine kadar ulaștığını gösterir. Zira șehzade Selim tahta geçtiğinde, musikide de gözle görülür birtakım değișiklikleri önerecek ve teșvik edecektir. Bu anlamda faslın dönüșümü hakkında Judetz' in söylediği "modernleșme ve Batılılașma" eğer bu dönem için kullanılmıșsa doğrudur. Fakat "Sanat müziği konserinin tiyatro sahnesinde sunulmasl..." șeklindeki ifadeler, bu pre-modern dönemi değil, farklılıkların yerleșik bir hal aldığı 19. yüzyıl ortalarını da ima eder. 19. yüzyıldaki fasıl ise öncü izleri ne klasik fasilda ne de daha öncesinde görülebilecek bir formata bürünmüș, Judetz'in de belirttiği gibi eğlence müziğinin içinden çıkan bir kol olmuștur.

\section{Yüzyıl Faslı}

Çok eski bir dönem olan nevbetlerden klasik fasıla geçiş süreci, yazılı kaynak yetersizliği sebebiyle tam olarak açıklanamamaktadır. Lakin șașırtıcı olan husus, 
bugüne daha yakın olan yani klasik fasıldan sonraki dönemin bilinmezliğidir. 19. yüzyılda fasıl mefhumu, daha eğlenceli, hareketli ve lirik bir formata dönüșür.

Müziğin en büyük hamisi olan saray, klasik dönem küme faslı'nda yüksek musikinin en büyük temsilcilerini himaye ederken aynı zamanda müziğe kendi zevki doğrultusunda yön veriyordu. 19. yüzyılda ise sarayın maaşlı Türk müziği mensupları, çoğunlukla sembolik bir anlam taşıyordu. Artık hükümdarlar iktidarın meșruiyetini, şeriata riayetini kontrol eden saray muhafızlarına değil, Avrupalılı fikrine sadakatini kontrol eden daha büyük kitlelere ispatlamak zorundaydı. Opera dinlemek yahut piyano çalmak bu yeni ülküye daha iyi hizmet edecek, sanata verdiği önemin göstergesi sayılacak ve müzik dinleme etkinliğinin yeni mekanları da konser salonları olacaktır. ${ }^{4}$

19. yüzyıl bașında yönetimdeki yapısal değișiklikler, dolaylı olarak müzikal yaşamın seyrini de etkilemiștir. Merkezî idare olan saraydan, ilișkide olunan Batılı ülkelerin sistemiyle denk düșecek pozisyonlar (nazır/bakan) atanan hükûmet sistemine geçiș yapılmış, bürokrasi sınıfı saraydan çıkıp șehrin farklı noktalarındaki hususî hizmet dairelerine tașınmıștır. Bu durum, Harem'den Enderun'a saray içi gündelik hayatın, teșrifatın da değișmesi anlamına gelir. Alaturka musiki mensupları için ise bu konaklar yeni cazibe noktası haline gelecektir. Sanatçının en büyük patronu,

4 19. yüzyıl, Sultan Abdülaziz gibi Alaturkaya daha meyyal padișahlar da çıkaracaktır. Ama bu, onların da Batı'ya ve geleneklerine karșı tamamen negatif tutum içinde oldukları anlamına gelmez. Yeni dönemin adeti olan tiyatrolara Sultan Abdülaziz'in verdiği maddî destekler için bkz. Namık Sinan Turan, “Osmanlı'nın Son Döneminde Opera”, Evrensel Kültür Aylık Kültür ve Edebiyat Dergisi, Ocak 2011, s. 25-26. tercihlerini politik emelleri doğrultusunda ayarlarken devlet erkanı eski ve yeni pratikler arasında daha kritik ve tarihî bir rol oynayacaktır.

Yüksek musiki ve gelenekleri, bir yandan Avrupa müziği ile kimyasını değiștirirken bir yandan da konak sahiplerinin zevkine uygun bir hale bürünecektir. Böylelikle saray üslubu ile șehir üslubunun yeni bir terkibi oluşacaktır. Bu yeni terkip, hem saray terbiyeli konaklarda hem eğlence yerlerinde hem de Batılı konser salonlarında yer bulabilecektir, zira bu kozmopolit ortamın meyvesi olduğu için tüm zevklere hitap eder. 20. yüzyılda bu yeni geleneğin sembol ismi Tanburî Cemil Bey'in yaptığı müzik için kimilerince söylenen "Istanbul musikisi" tabirinin (Cemil 2002, 13) altında da bu sosyal temeller yatıyor olmalıdır. Șehir musikisi ile saray musikisi öteden beri keskin çizgilerle ayrılmamıștır. Ancak klasik dönemde böylesi yoğun ve mecburî ilișkiler olmamıș, seyr-i tabii içinde makul alıșverișler yașanmıș olmalıdır.

Öte yandan 17. yüzyıl başlarından itibaren İstanbul, aldığ yoğun göçler sonucunda bir sosyo-kültürel değișime de öncülük eder. Cem Behar $(2020,59)$ bu durumu, "bir yandan yoğun kırsal göçle birlikte İstanbul'a gelen yöresel müzikler ve çalgılar, bir yandan da șehirde yeni varlıklı tabakanın olușması bașkentte musiki üretim ve icrasının farklı mecralara yönelmesine de sebep olmuștur," șeklinde açıklar. Ayrıca İstanbul musiki hayatında yașanan bu çeșitlenme, tercih edilen repertuvara da yansımıs, ciddi müzik ve eğlence müziği birbirine daha çok yaklașmıștır. Dinleyicinin de icraya iștirak ettiği bir tertip olan fasıl, bu sosyalliğin içerisinde icra edilen yeni müziğin adı olmuş ancak 
içerdiği formlar ve üslup sarayda icra edilen evvelki fasıllardan ayrı bir hüviyet kazanmıștır. Sözlü formlar, yalnızca akılda kalıcı melodilerden oluşan küçük șarkılara yerini bırakmış, Peșrev ve Saz Semaisi aynı kalmıșsa da üslubu fasıldaki diğer eserlerle bütünlük olușturacak șekilde hareketlenmiștir.

Eskiden beri musiki himaye merkezlerinden biri olan șehir, saraydan daha önemli bir konuma erișmiștir. Bu yeni faslın, Müslüman ve Gayrimüslim ìstanbul halklarının ortak algısında șekillenmiș, șehrin eğlence müziklerinden etkilenmiş bir tertip olduğunu tahmin etmek zor değildir. Bu durumu kuvvetlendiren delilleri, etkisi bugüne uzanan meyhane müziklerinin icra üslubunda görebilmek mümkündür. Kamusal alandaki gücünü pekiștirmeye bașlayan müzik, Cumhuriyet gazinolarının öncülleri olan kahvehaneler ve meyhanelerde bir tüketim unsuru haline gelmiștir.

\section{Kahvehane-Meyhane}

Osmanlı eğlence hayatı içerisinde önemli bir yere sahip olan meyhane kültürünü anlamlandırabilmek için, bu mekânların atası olarak adlandırabileceğimiz kahvehanelere ve kültürüne değinmek yerinde olacaktır. Yukarıda da bahsedildiği gibi, farklı mekânsal arayıșlar içerisine giren musikinin halk ile buluștuğu mecralardan biri de 16 . yüzyıldan itibaren Osmanlı topraklarında yaygınlașmaya bașlayan kahvehanelerdir. Öyle ki, Direklerarası'nın meșhur Fevziye Kıraathanesi, 19. yüzyıl müzik kültürünü yöneten önemli bir mekân olarak tebarüz eder. Her türlü eğlence unsuruna yer veren bu mekân, dönemin profesyonel sazende ve hanendelerinin icra ettiği fasılları muhafaza etmesi açısından da önemlidir. Fevziye Kıra- athanesi'nin sahne programında Ramazan aylarında her gece -Kadir geceleri hâriç-, diğer aylarda ise yalnızca Cuma ve Pazar günleri olmak üzere Karagöz, meddah, kukla, tiyatro gösterileri ve fasıl icraları olduğu görülmektedir (Mimaroğlu 1971, 5727). Ramazan ayında iftar ve sahur arasındaki canlılığıyla bilinen Direklerarası'nın bir geleneği olacak ki, bu ayda Fevziye Kıraathanesi'ndeki fasıl icraları iki makamdan oluşacak ve dört saat sürecek şekilde düzenlenmiştir (Pekin 2015, 55). Kemençeci Vasilâki (1845-1907) ve Kemanî Tatyos Efendi (1858-1913) gibi isimlerin yönetiminde gerçekleștirilen ve günümüzdeki fasıl icrasıyla benzerlik gösterdiği düşünülen fasılların dinleyicileri de bir hayli önemli isimlerdir. Tanburî Cemil Bey (18711916), Rauf Yekta Bey (1871-1935), Lem'î Atlı (1869-1945), Zekâi Dede (ö. 1897) gibi Türk müziğinin gelișimine katkı sunan müzisyenlerin bu fasıllara dinleyici olarak katılması (Mimaroğlu 1971, 5727), 19. yüzyıl fasıl kültürü ve yaygınlığı hakkında önemli referanslar sunmaktadır.

Sanatçıların uğrak yeri hâline gelen kahvehaneler, yerini meyhanelere bırakana kadar fasıl icralarının da bel kemiği olmuștur. 19. yüzyıl bașında yönetimde gerçekleșen yapısal değișimlerden halka açık müzik ve eğlence mekânları da etkilenmiș ve kahvehanelerin yerini meyhaneler almaya bașlamıștır. Bașkentteki meyhanelerin görünürlüğü artmış, müzik ile olan ilișkileri kuvvetlenmiș ve artık meyhaneler "marjinal bir mekândan olağan bir eğlence mekânına" evrilerek kahvehanelerin popülaritesine son vermiștir (Çokuğraș 2016, 148).

Tanzimat Dönemi'nin Osmanlı eğlence hayatına bıraktığı bir bașka miras ise ga- 
zinolardır. Kahvehanelere nazaran daha geniș ve çeșitli halk kitlelerini ${ }^{5}$ ağırlamıș olan ve ilk örneklerine 20. yüzyılın bașlarında rastlanan gazinolar, bünyelerinde musikiyi de barındırırlar. Gazinonun ilk örneklerinden olan Emperial Bahçesi'nde haftanın belirli günlerinde Kemanî Tatyos Efendi'nin incesaz programı yaptığ $1^{6}$, Fener İskele Gazinosu'nda da tanınmış müzisyenlerin sahne aldıkları, aktarılanlar arasindadır (Zat 1994, 379).

Bahse konu olan 19. yüzyılın bu çok renkli sosyal tablosunun içinde müzik, bütün katmanlar için önemli bir yer tutmaktadır. Avrupa müziği icra ve dinleme disiplinleri ile tanışan Türk ekabiri, müziğin ișleyișine yönelik teknik ve teorik birtakım arayıșlar ve birbirinden farklı "çözüm" önerileri sunmușlardır. Lakin fasıllar, değișim tartıșmalarından etkilenmeksizin, müzisyenlerin iç dünyalarının en tabii bir yansıması gibi durmaksızın icra edilmiș ve bu anlayışa uygun çok sayıda eser verilmiștir.

\section{Repertuvar}

Dönem, büsbütün Batı'ya dönük profiller çıkardığı kadar köklere yönelmek gerekliliğini vurgulayan aydınlar da yetiștirmiștir. Bu yönelișin amacı, Batı'ya yenilmișliğin tezahürüdür ve eski parlak günleri öne çıkararak bugünü Batı normlarına eriștirmektir. Rauf Yekta Bey, musikișinaslar arasında çareyi geçmiște ara5 Cumhuriyet'in ilânının ardından varlığını sürdürmeye devam eden ve hatta piyasa müziğinin tek kalesi hâline gelen gazinoların, 1950-1960 yılları arası Türkiye Cumhuriyeti iktidarında olan Demokrat Parti döneminde bu demografik çeșitliliği daha ziyade sermayenin yeni sahipleri olan Anadolu göçmenlerinden olușacaktır. Detaylı bilgi için bkz. Bedirhan Büyükduman, "Demokrat Parti Döneminde Uygulanan Kültür Politikalarının Türk Makam Müziğine Yansımaları", Yayınlanmamış Yüksek Lisans Tezi, Yıldız Teknik Üniversitesi SBE, 2020, s. 9597.

6 Kahvehanelerde icra gösteren fasıl gruplarına bu dönemde "incesaz takımı" da denilmektedir. Bkz. Ersu Pekin, age, 2015, s. 55. yanların en bașında gelenlerdendir. Rauf Yekta Bey'de geçmișin, özellikle de III. Selim döneminin güzelliklerini vurgularken "'sâdelik içinde asâlet ve metânet' üslûbu" deyip günün müziğini ise bozuk olarak ișleyen ve dıșarıdan müdahaleyle "terakkiye" [ilerlemeye] (Özdemir 2010, 135) muhtaç bir vaziyet içerisinde göstermek gayesi vardır. Ancak bütün bu görüșlerini, tıpkı Batılı konsertistler gibi giyinmiş “yeknesak siyah kostümlü sazendeler"in (Özdemir 2010, 131) önünde bir konferans șeklinde sunmaktan çekinmez. Yazarın asıl meselesinin, konser gibi Batıdan devşirme adetlerle mücadele değil klasik üslubun öne çıkarılması olduğu açıktır. Ne var ki tıpkı bugün gibi o zaman da piyasa ve klasik denilen mefhumlar kalın çizgilerle ayrıșmıș değildir. Darülelhan tarafindan yapilan konserleri izleyip yorumlayan Rauf Yekta Bey'in konserde icra edilen klasik bestecilerin eserlerini öne çıkarması ve diğer eserleri de "hoș-âyende ve șetâretli eserler huzzârı neșelendirdi" (Özdemir 2010, 128) gibi dinleyicinin keyiflenmesi için icra edilmiș hareketli eserler gibi sözlerle değerlendirmesi dikkat çekicidir. Yine buna benzer konserlerden birinde icra edilen Hicazkâr fasını değerlendiren Rauf Yekta Bey șu sözleri sarf eder: "Bu fasılda okunan șarkılar hakîkaten hüsn-i intihâb edilmiș idi. Piyasada okunan ve -mülgâ saltanat devrinin harem ağaları gibi- ekserisi birbirine benzeyen Hicâzkar şarkılardan herkese gınâ geldiği için (Yok hilâfım...), (Şeb-tâ seher...) gibi șarkıları sâmi'în büyük bir

7 “(Tanbûrî Emin Ağa)’nın peșrevi -bestekârının zamanından beri piyasada uğradığı bin türlü tahrîfâttan âzâde olarak-çalındı ve mûsikîmiz Üçüncü Selim asrında hâiz olduğu 'sâdelik içinde asâlet ve metânet' üslûbu hakkında dinleyenlere bir fikir verdi. (Dârülelhân) üstâdlarının âsâr-ı eslâfa gösterdikleri bu hürmetkârlık șâyân-ı teșekkürdür." Bkz. Hüseyin Özdemir, "Rauf Yektâ Bey’in, Resimli Gazete, Yeni Ses ve Vakit Gazetelerinde Mûsikî ile ilgili Makalelerinin İncelenmesi", Yayınlanmamıș Yüksek Lisans Tezi, İstanbul, Marmara Üniversitesi SBE, 2010, s. 125. 
alâka ile dinlediler" (Özdemir 2010, 116). Piyasada okunan Hicazkâr șarkıların birbirine benzerliğini saltanat devrinin harem ağalarının birbirine benzemesiyle teșbih eden Rauf Yektâ Bey, bu nedenle konserdeki özgün Hicazkâr parçaların dinleyenler tarafından beğenildiğini belirtmiștir. Lakin burada kendisinin övgüyle bahsettiği Âsâriye Camii İmamı İbrahim Efendi ${ }^{8}$ (ö. 1880?)'ye ait "Yok hilafım hem müdârâ bir yana" isimli Ağır Aksak șarkı ve "Şeb-tâ seher akar su gibi çağlar ağlarım" isimli Devrihindi usûlündeki Hașim Bey'in (1815-1868) şarkısı, klasik döneme değil 19. yüzyıla ait eserlerdir. ${ }^{9}$ Eserler yazarın benimsediği "sadelik ve metanet üslubu" içerisinde icra edilmiș olduğu için muhtemelen dikkate değer görülmüștür. Fakat her halükârda Ağır Aksak șarkıların fasıın ilk sırasını alıp Beste'ye galip geldiği açıktır. 19. yüzyıldan 1950'lere değin uzanan süreçte nadiren klasik fasıl formları bestelenmiștir ancak bu süreç direklerarası faslın en verimli çağı olmuștur. ${ }^{10}$

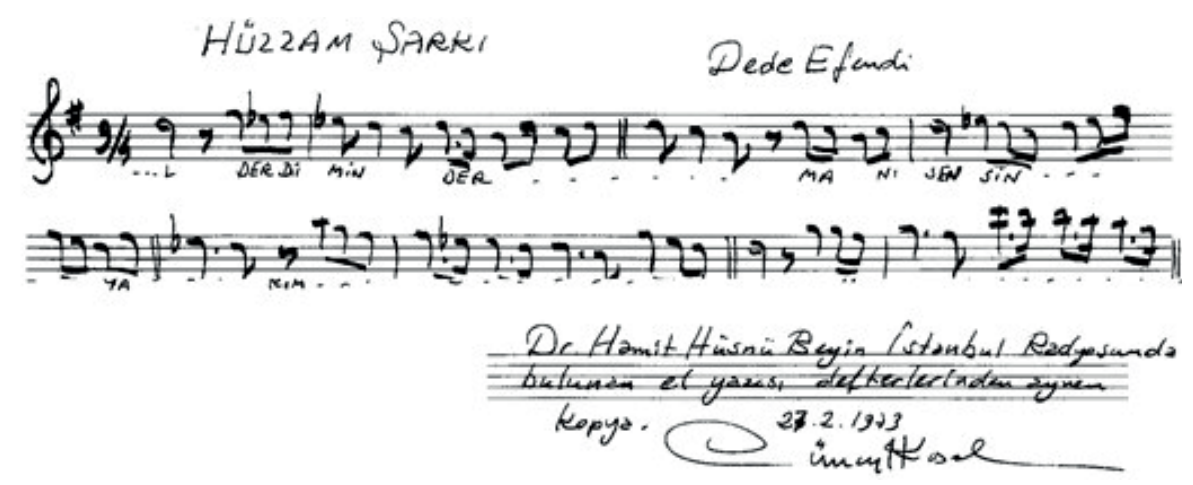

Nota 1. İsmail Dede Efendi'ye atfedilen Hüzzam Şarkı'dan kesit.
Tıpkı klasik fasıl (takım) repertuarında formların belli bir standarda oturmuș olması gibi direklerarası faslı da belli bir usûl sırasını ve icra adabını takip eder. Tablo 1'de görüldüğü üzere bu usûl tertipleri içinde șarkı formlarının değișkenliği söz konusudur. Ancak örneklerdeki bütün terkiplerde, ilk üç sırayı paylașan Peșrev, Ağır Aksak ve Sengin Semai usûlü ve formunun ittifakla kabul edildiği görülmektedir. Bu noktada çalıșmada, bu üç form ele alınarak örneklendirilmiş ve fasıl icrası açıklanmaya çalıșılmıștır. Calıșmada ele alınan örnek fasıllarda, hemen bütün fasıllarda olduğu gibi en az iki adet mızraplı saz (kanun, ud ya da tanbur) bulunduğu gözlemlenmiştir. Bu sebeple toplu icra içinde sazların mün-

8 Detaylı bilgi için bkz. Yılmaz Öztuna, “ibrahim Efendi [Âsâriye Hatîbi]”, içinde Büyük Türk Musikisi Ansiklopedisi, İstanbul: Milli Eğitim Basımevi, 1969, c. 1, s. 292.
9 İsmail Dede Efendi'ye nispet edilen Ağır Aksak usûlündeki Hüzzam șarkı "Derdimin dermanı sensin ey peri” (bkz. Nota 1), 9/4 usûlünün o dönemde de var olduğunu düșündürebilir fakat bu șarkının Dede Efendi'ye sonradan atfedilmiș olma intimali daha kuvvetlidir. Yine Numan Ağa'ya atfedilen aynı usûldeki Nihavend șarkı "Âkıbet viran edip gönlüm felek" ve Hacı Sadullah Ağa'ya atfedilen Hicazkâr șarkı "Gel seninle yarın ey serv-i revân" için de tahminimiz bu yöndedir. Hacı Sadullah Ağa'nın eserinin Ağır Aksak usûlünün ilk mahsullerinden olduğunu kabul eden bir çalıșma için bkz. Feridun Öney, "Lenkfahte Bestelerin Ayırıcı Özellikleri”, Yayınlanmamıș Yüksek Lisans Tezi, İstanbul, İstanbul Teknik Üniversitesi SBE, 1993, s. 5. Bu bestelerin rivayet edildiği bestecilerin doğru olduğu kabul edildiği takdirde șarkı formunun kendisinden sonra yaygınlaștığı vurgulanan $\mathrm{HaCl}$ Arif Bey dönemi ile değișimi açıklamak formülü de bir bakıma yanlıșlanmaktadır. Fasıldaki üslup değișimini Hacı Arif Bey’le ilișkilendiren bir çalıșma için bkz. Osman Nuri Özpekel, "Türk Mûsıkîsinde Fasıl ve İcra”, Yeni Türkiye, 2014, s. 1132.

10 Şarkı formunun yükseliși Hacı Arif Bey (1831-1885) ile sembolleștirilse de Tanburî Mustafa Çavuș, İsmail Dede Efendi ve III. Selim gibi bestecilerin verdikleri eserler șarkı formunun daha geçmișe gittiğinin kanıtlarıdır. Lakin bu șarkıların direklerarası fasıldaki gibi bir gelenekle icra edildiği bilgisine sahip değiliz. Ancak Hacı Arif Bey'den bu yana özellikle direklerarası faslına uygun eserler veren bestecilerden Kemanî Tatyos Efendi, Bimen Șen (1873-1943), Udî Selanikli Ahmed Bey, Sermüezzin Rifat Bey (1820-1888), Leon Hanciyan (ö. 1947), Lemi' Atlı, İsmail Hakkı Bey (1866-1927) gibi isimler zikredilebilir. 
ferit olarak seçilmesi ve notaya alınması büyük zorluk yaratmaktadır. Notaya alırken kabul edilen referans yalnızca bir enstrümanın yaptığı süslemelerin değil saz heyetindeki bütün enstrümanların yaptığı süslemelerin ortalamasını yaz- mak veya baskın duyulan melodi çizgisini notalamak șeklinde olmuștur. Notalarda görüleceği üzere farklılıkları belirtmek adına ilk satırda eserin notası, ikinci satırda fasıl icrası ve en alt satırda ritim notas ${ }^{11}$ yer almaktadır.

Tablo 1. Hakkı Derman, Emin Ongan ve Ergin Kızılay tarafından tertip edilmiș ikișer fasıl ve dahil edilen formlar.

\begin{tabular}{|l|l|l|l|l|l|}
\hline \multicolumn{2}{|c|}{ Hakkı Derman } & \multicolumn{2}{c|}{ Emin Ongan } & \multicolumn{2}{c|}{ Ergin Kızılay } \\
\hline \multicolumn{1}{|c|}{ Hicaz } & \multicolumn{1}{|c|}{ Hüzzam } & \multicolumn{1}{c|}{ Hüzzam } & Tähirbuselik & Kürdilihicazkâr & \\
\hline Peşrev & Peşrev & Peşrev & Peşrev & Peşrev & Peşrev \\
\hline Ağır Aksak & Ağır Aksak & Ağır Aksak & Ağır Aksak & Ağır Aksak & Ağır Aksak \\
\hline Ağır Aksak & Ağır Aksak & Ağır Aksak & Sengin Semai & Ağır Aksak & Sengin Semai \\
\hline Sengin Semai & Ağır Aksak & Devr-i Hindî & Türk Aksağı & Sengin Semai & Düyek \\
\hline Ara Taksim & Ara Taksim & Ara Taksim & Ara Taksim & Ara Taksim & Ara Taksim \\
\hline Ağır Aksak & Sofya & Aksak & Müsemmen & Curcuna & Curcuna \\
\hline Sengin Semai & Aksak & Aksak & Curcuna & Yürük Semai & Aksak \\
\hline Aksak & Curcuna & Aksak Semai & Aksak Semai & Aksak & Aksak \\
\hline & Sofyan & & & Aksak & Sofyan \\
\hline
\end{tabular}

\section{İcracılar}

Klasik ve fasıl icraları devam ederken 20. yüzyıl modernizminde müzikal kimliklerin mahiyeti değișmiș ve müzik türlerinin iç içe geçtiğ i modern bireysel terkipler öne çıkmıștır. Bununla birlikte bu dönemde tek yönlü bir müzisyen karakterine sık rastlanmaz. Sözgelimi fasıl icrasında ustalașmış bir müzisyen, dinî müziklerde de varlık gösterebilir yahut

11 Makalenin genelinde kullanılan ritim notasyonu, geleneksel çift çizgili gösterimden farklı olarak tek çizgi üzerinde gösterilmiștir. Bu gösterime göre sapı yukarı yönlü olan notalar bas sesi (düm), așağı yönlü olanlar ise tiz sesi (tek, te, ke, kâ) belirtmektedir. bireysel modern duyușları önceleyen bir sazende fasıl icra edebilir. Bireysel, modern bir terkibin peșinde olan son dönem kemençe sanatçılarından Derya Türkan'ın fasıl icra etmesi yahut geleneksel üslubu benimseyen tanbur sanatçısı Özer Özel'in deneysel çalıșmalarda da yer alması buna örnek gösterilebilir. Türk müziği icracılarındaki bütün bu üslup karmaşasına ve günden güne icra alanını kaybetmesine rağmen direklerarası fasıl geleneğindeki icra üslubunun önemli bir değişikliğe maruz kalmadan 
halen devam ettiği söylenebilir. ${ }^{12}$

20. yüzyılda Ahmet Yatman (1897-1973), Şerif İçli (1899-1956), Yorgo Bacanos (1900-1977), Şükrü Tunar (1907-1962), Hakkı Derman (1907-1972), Kadri Șençalar (1912-1989), İsmail Şençalar (19171992), Fahrettin Çimenli (1934-2018), Ergin Kızılay, Ahmet Meter gibi isimler direklerarası fasıl icrasının en büyük sazendeleri arasındadır. Tıpkı melodik saz icracılarında olduğu gibi, ritim çalgısı da Güngör Hoșses (1938-2014), Atilla Mayda (1936-2019), Seyhun Çelik, Ahmet Kulik gibi isimlerin icraları dikkate alındığında klasik üsluba nazaran meșruiyetini ilân etmiş ve ritim icracısının özgün tavrından etkilenmeye bașlamıștır. Modernizme karșın geleneği bünyesinde muhafaza eden direklerarası fasıl müziğinde, hanendeliğinin yanında elindeki tef ile aynı zamanda bir sazende olan serhânendelik olgusu da süregelmektedir. Bu geleneğin temsilcileri arasında Kemal Gürses (19131991), Kasım İnaltekin (1925-2005), Sami Özkanlı (1926-1994), Nurettin Çelik, Mustafa Keser, Mehmet Güntekin, Mustafa Doğan Dikmen gibi isimler zikredilebilir.

\section{Melodik İcra Üslubu}

Türk müziğinin, eser icrasında nağme grafiğinden sapma eșiğinin 19. yüzyılda daha da esnetildiği anlașılmaktadır. Judetz'in ifadesiyle artık bu dönemde adeta "icracilar ve besteci arasındaki rekabet ruhu" çok daha belirgin olmaya bașlar. Öyle ki, faslın öteden beri ismi ve 12 Bugünün içkili eğlence mekanlarında icra edilen, farklı müzik türlerinin repertuarlarının icra edildiği ve Türk müziği ile kurulabilecek tek ilișkisi ud, kanun, darbuka gibi geleneksel sazlar ile çalınması olan ve eski bir isimlendirmeden miras olarak "fasıl" olarak anılan müzik, bu makalenin sınırları içinde değildir. İstanbul eğlence müzikleri bağlamında söz konusu güncel fasılların da ele alındığı bir çalıșma için bkz. Fikret Merve Eken, “19. Yüzyıldan Günümüze İstanbul Eğlence Hayatında Fasıl” (Yayınlanmamıș Yüksek Lisans Tezi, İstanbul Teknik Üniversitesi SBE, 2007). fonksiyonu değissmeyen tek unsuru olan Peșrev'in bol süslü icrası, klasizm tarafgiri Rauf Yekta Bey'in çıkıșlarına sebep olmuştur. İtirazlarına geçmişten örnek vermesi șaşırtıcı değildir; Rauf Yekta Bey, Tanburî Büyük Osman için șu rivayeti dile getirir:

"Eserlerini tahrif edenlere karșı pek ziyâde canı sıkıldığı meșhur olup bir kıraathanede 'ușșak' pîșrevinin teslimine geçilecek mahalline bir parça ilâve eden bir kanûnîyi dövmeğe bile kalkıștığı mervîdir. Şu rivâyete nazaran müșârünileyhin bugün iâde-i hayât etmesi kâbil olsa pîșrevlerinin uğradığı tahrifat gûnâ-güne ne suretle mukâbele edeceği câ-yısuâldir." (Öncel 2010, 119)

Rauf Yekta Bey'in bayağı bulduğu peșrev icrasındaki canlılığın, dönemin ses kayıt yıldızı Tanburî Cemil Bey’in icralarında görülebileceği malumdur. Klasik eserlerin sade icra edilmesi yönünde Rauf Yekta Bey'in sözünü ettiği yol da devam edegelmiștir. ${ }^{13}$ Ayrıca belirtilmelidir ki esasen klasik ve fasıl icrası birbirinin tam zıddı değildir; benzer süsleme araçları her iki tarzda yaklașık olarak aynıdır. Farklılaşan durum, bu süslemelerin sunum șekliyle alakalıdır; bestenin önüne geçmekte mütereddit olan klasik icrada eklemeler çekingen ve mümkün mertebe sessiz olurken fasıl icrasında ise süslemeler -özellikle mızraplı sazlardaalabildiğine vurgulu çalınır. Mesud Cemil

13 Örneklerde ișleyeceğimiz fasıl șarkılarından "Yıllar ne çabuk geçti” isimli Sengin Semai usûlündeki Hicaz șarkının (beste: Bimen Șen) önünde ve sonunda bașka șarkı olmaksızın münferiden ve fasıl tavrı dıșında yorumlanmıș örnekleri için bkz. Münip Utandı, Yıllar ne çabuk geçti, CD, Aynalıkavak'tan Kalamıș'a (Kalan Ses Görüntü, 1995), https://open.spotify.com/ track/4BRQHAtQH9l8OEFKdwhBld; Nesrin Körükçü, Yıllar ne çabuk geçti o günler arasından, CD, Bir Şarkıdır Yașamak Box Set (Bonus Müzik Prod., 2013), https:// open.spotify.com/track/4Kw20WvCD6jzektO2oDnNf; 
Bey'in (1902-1963), klasik tanbur tavrına yakın bir üslupla solo olarak icra ettiği Kemençeci Vasil'in (1845-1907) Kürdilihicazkar Peșrevi'nde ${ }^{14}$ temkinli süsle-

meler ve uzun sessizliklere ayrılan cesur sadeleștirmeler açıkça görülmektedir (bkz. Nota 2).

Kürdilihicazkar Peşrev

Usûl: Ağır Düyek

Mesud Cemil'in icrasindan kesit

Kemençeci Vasil
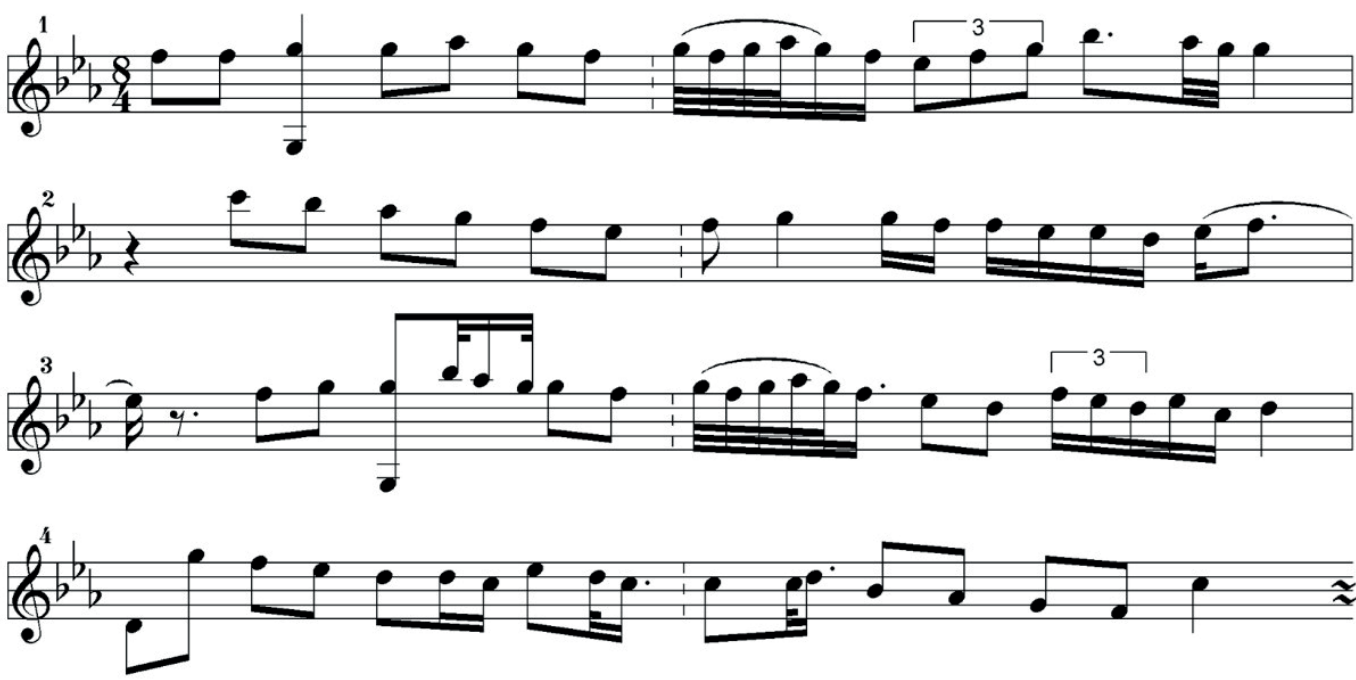

Nota 2. Kemençeci Vasil'in Kürdilihicazkar Peșrevinin Mesud Cemil tarafından tanburla solo icrasından kesit.

Bestekârla yarıșırcasına icra ise bugüne uzanan bir üslup olarak devam eder. Örneğin Kemençeci Vasilâki'nin mezkûr peșrevi, 1950'lerde Kemal Gürses yönetimindeki bir Kürdilihicazkar faslı içinde çalınırken daha hareketli bir formata rünür. ${ }^{15}$ Mızraplı sazların bir vuruș ve iki vuruș hatta bazen yarım vuruș nispetindeki notaları onaltılık ve otuzikilik parçacıklara bölerek çaldığı görülmektedir. ${ }^{16} \mathrm{Bu}$ tür bölünmelerin en basit șekli bir notayı kendi cinsinden notaya bölmek, yani çiftlemek șeklinde olanıdır. ${ }^{17}$ Bölünmeler daha ziyade, melodilerde yapılan oyunlarla çeșitlendirilir. Örneğin inici melo14 https://open.spotify.com track/400cHfTRnBw0gzlhP $\mathrm{Km}$ 9LH?si=3f308684616c4f06

15 Bkz. Kemal Gürses, Kürdilihicazkar Peșrevi, CD, Kürdilihicazkar Faslı Hüzzam Faslı (Uluçınar Müzik, 1994), https://open.spotify.com/ track/3TVSog8EdjYL1LymDDpaqU.

16 Bkz. Nota 3.

17 Bkz. Nota 3, Bölüm a.

18 Bkz. Nota 3, Bölüm b. di grafiğinde Türk müziği icra çeșitlerinin (dinî, klasik, fasıl, artistik icra vb.) birçoğunda yapılan çarpmaların nota gibi duyurulması bunlardan biridir. Sesli çarpma da denilen bu hareket, bilindiği gibi her bir nota arasına bir sonraki notanın eklenmesiyle yapılır. ${ }^{18}$ Direklerarası fasıl geleneğinin temel farkı ise daha önce de belirtildiği gibi bunların vurgulu olarak icra edilmesidir. Nota 3'te üçüncü ölçü ile dördüncü ölçü arasında kalan, altı çizili olarak işaret edilen bölümde, bir mızraplı sazın (ud) yaklașık yedi vurușluk bir süre içinde onaltılıktan daha büyük nota çalmadığı görülecektir. Yine aynı bölümde, nağmenin üst ve alt seslerine sapmalar, uzun notalarda arpej, inici notalarda sesli çarpmalar ve benzeri süslemelerin bir arada bulunması, fasıl icrasındaki ritmik sürekliliği sağlayan karakteristik araçlardır. 
Kürdilihicazkar Peşrev

Kemal Gürses yönetimindeki fasıl icrasindan

Usûl: Ağır Düyek
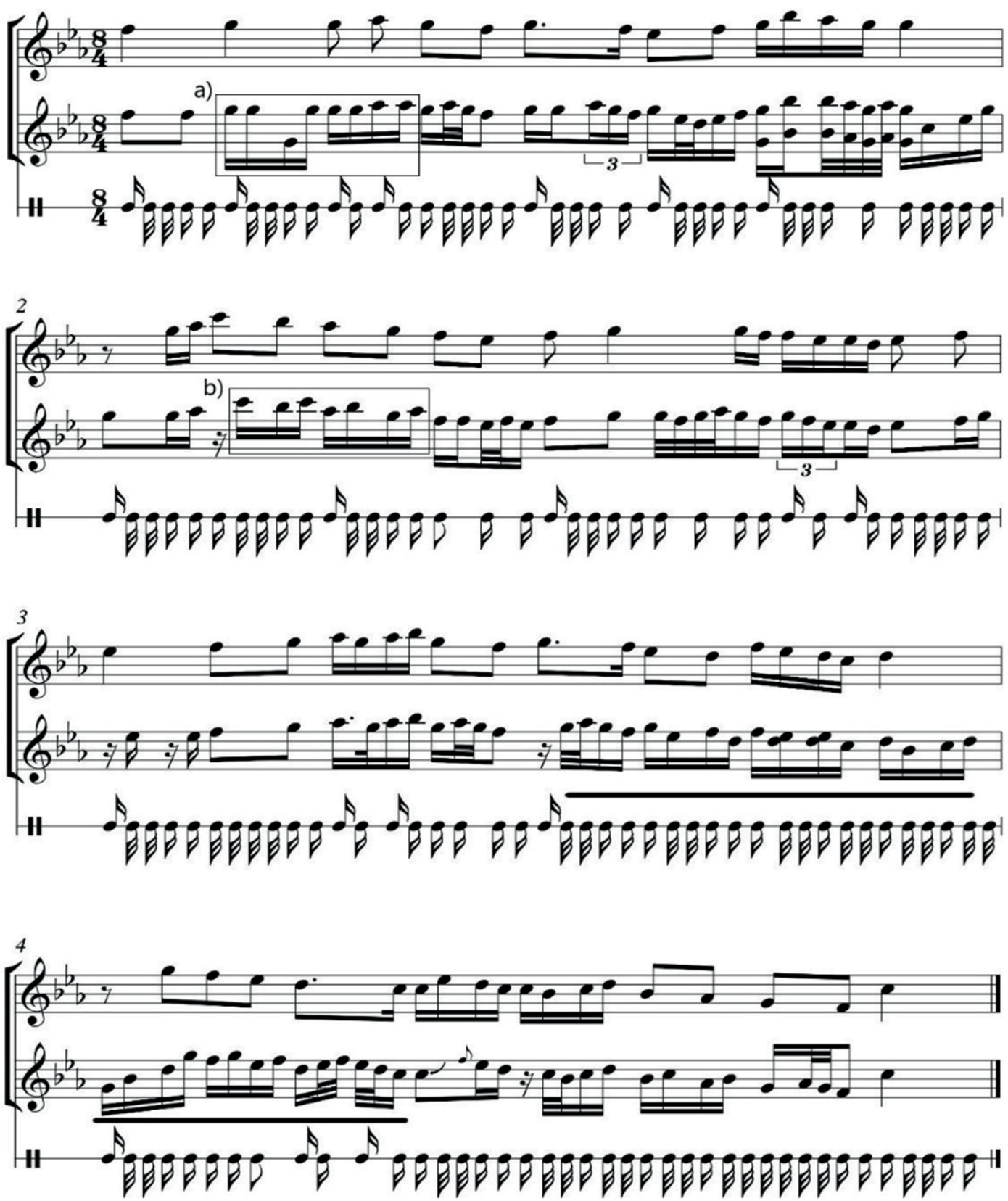

Nota 3. Kemençeci Vasil’in Kürdilihicazkar Peșrevinin Kemal Gürses yönetimindeki Kürdilihicazkar Fasıl icrasından.

İncelenen örnekteki üslup sadece bu Dolayısıyla peșrevlerin icrasındaki bu haeseri çalan heyete özel bir yorum olma- reketlilik, faslın diğer formlarının icramakla beraber, genel olarak fasıl, bașın- sında da geçerlidir. Nota 3'te gösterilen dan sonuna bir bütünlük içinde çalınır. örnekleri, aynı eseri icra eden farklı bir 
saz heyetinin farklı bir dönemdeki icrasinda da bulunabilmektedir. 1993 yılında Ergin Kızılay yönetimindeki heyetin icra ettiği Hüzzam faslın peșrevinden (Tanburî Büyük Osman Bey) teslim bölümü ${ }^{19}$ ve Ağır Aksak șarkının ${ }^{20}$ (Sabrımı gamzelerin sihr ile târâc edeli) icradaki zemin bölümü; 2019 yılında Mehmet Güntekin yönetimindeki İstanbul Fasıl Topluluğu tarafından icra edilmiș bir Hicaz faslındaki" Sengin Semai için ise "Yıllar ne çabuk geçti" isimli șarkının nakarat bö- lümünün notaları Nota 4, 5, 6 ve 7'de görülebilir. Bu eserlerde de yine peșrevde görüldügüu gibi melodi grafiğinin temel çizgisinden kopmadan ahenk seslerin duyurulduğu küçük bölünmeler, ${ }^{22}$ çiftlemeler, ${ }^{23}$ inici nağmelerde üst ve alt seslere sapmalar, ${ }^{24}$ uzun notlarda arpejler ${ }^{25}$ vardır. Ayrıca notayı bir noktadan bașka bir noktaya götüren köprü melodiler ${ }^{26}$ ve uzun soluklu notalarda küçük motifler olușturma geleneğinden örnekler ${ }^{27}$ de işaret edilebilir.

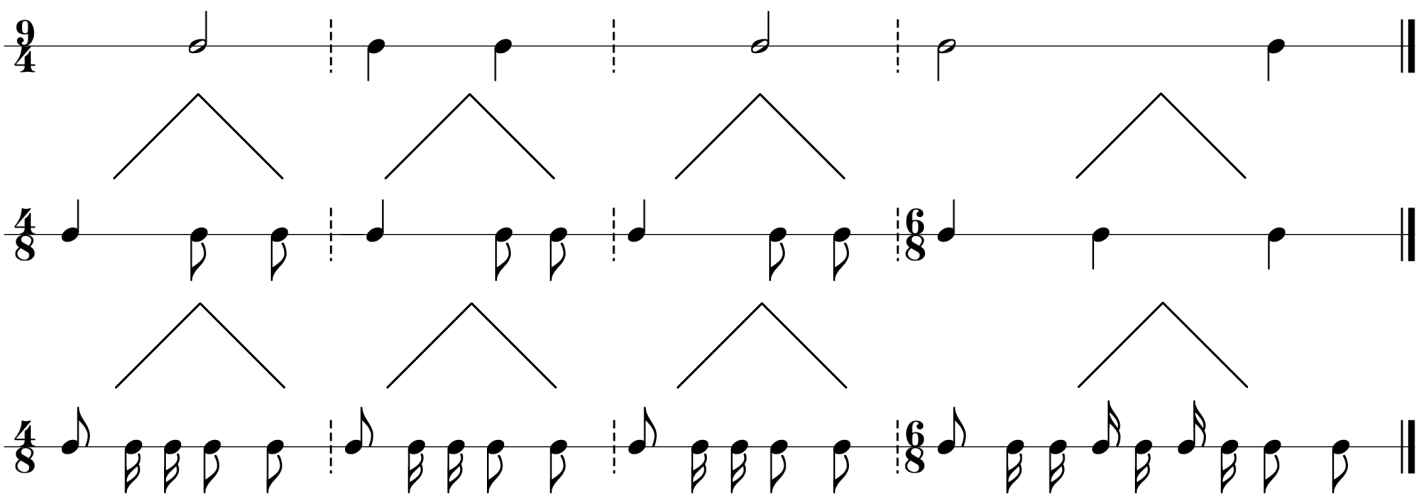

Şekil 1. 9/4’lük Ağır Aksak Usûlünün Meșk Aktarımındaki Gösterimi.

19 Bkz. Ergin Kızılay, Hüzzam Peșrevi, CD, Süper Fasıl Vol. 2 (Kalite Ticaret Plak, 1993), https: / /open.spotify. com/track/3p6KUh8X8q9Wm0XuSawRA7.

20 Bkz. Ergin Kızılay, Hüzzam Peșrevi, CD, Süper Fasıl Vol. 2 (Kalite Ticaret Plak, 1993), https://open.spotify. com/track/6kDg5RQYMjmc35BqQA8C6a.

21 Bkz. Hicaz - İstanbul Fasıl Topluluğu - TURING 16.04.2019, (TURING KÜLTÜR SANAT Youtube kanal,, 24.04.2019), https://youtu. be/s7jtEZiT28Y?t=937, erișim tarihi: 24.11 .2020 .
22 Bkz. Nota 5, Bölüm e; Nota 6, Bölüm d; Nota 7, Bölüm d.

23 Bkz. Nota 5, Bölüm b, c, e; Nota 7, Bölüm d.

24 Bkz. Nota 4, Bölüm a, b; Nota 6, Bölüm a.

25 Bkz. Nota 6 Ölçü 4.

26 Bkz. Nota 5, Bölüm d; Nota 6, Bölüm e.

27 Bkz. Nota 6, Bölüm c; Nota 7, Bölüm c. 


\section{Hüzzam Peşrev}

Usûl: Devr-i Kebir

Ergin Kizalay yōnetiminde Hüz:am Fasıl Icrasmdan

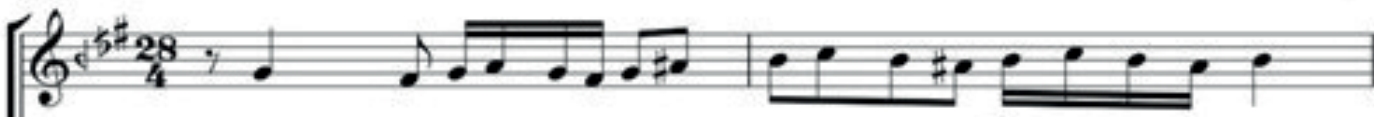

a)
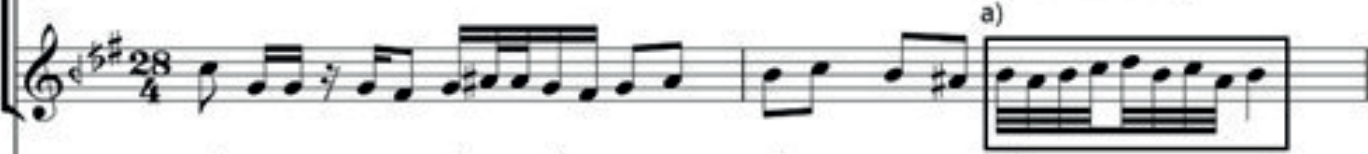

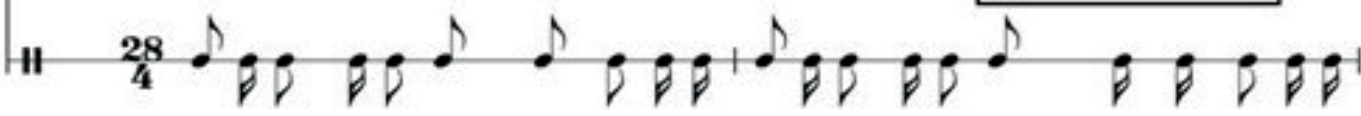
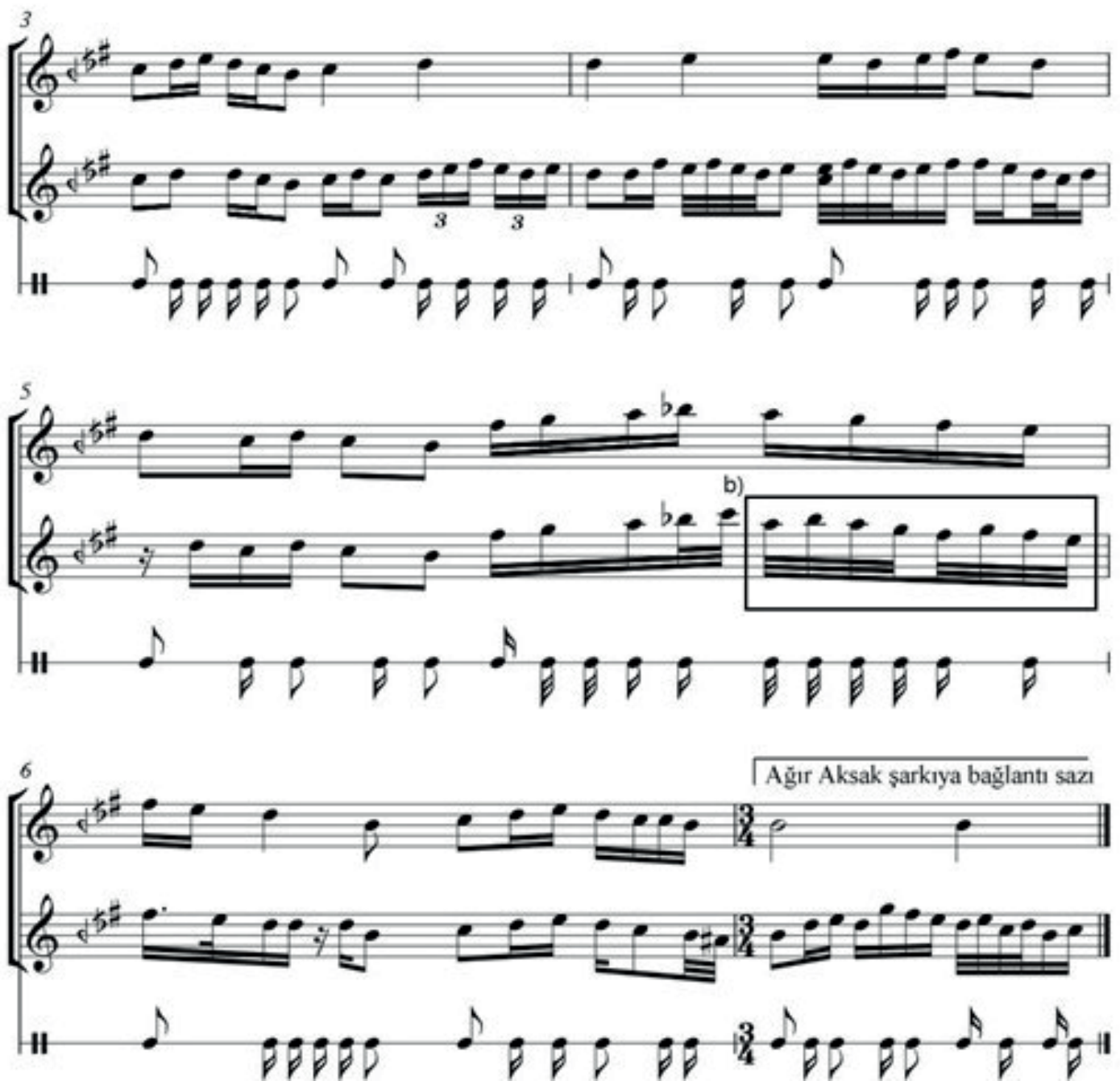

Nota 4. Ergin Kızılay yönetimindeki fasıl heyetinin icrasından Osman Bey’in Hüzzam Peșrevinin Mülazime bölümü. 


\section{Sabrımı Gamzelerin Sihr ile Tarac Edeli}
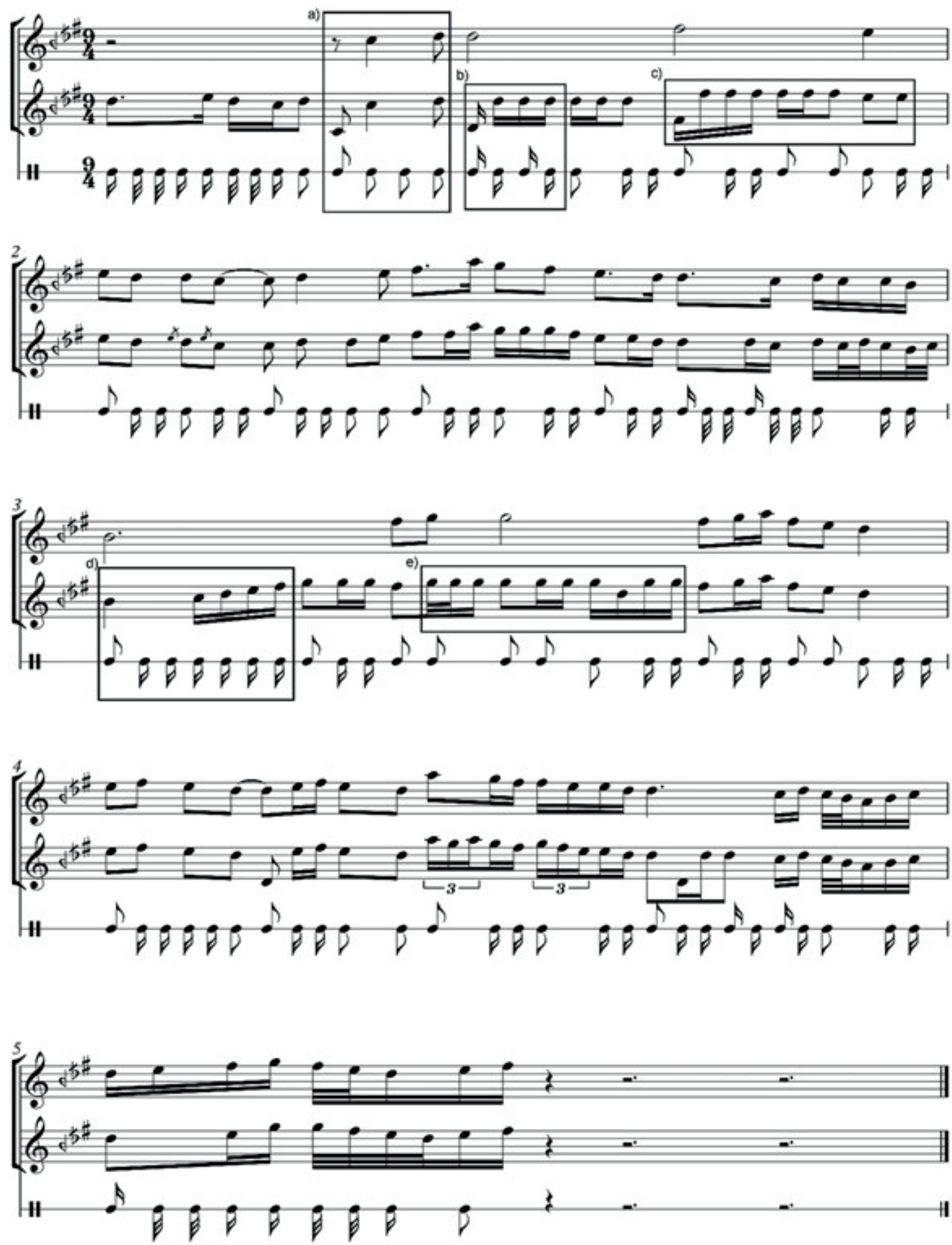

Nota 5. Ergin Kızılay yönetimindeki fasıl heyetinin icrasından “Sabrımı gamzelerin sihr ile tarac edeli” șarkısı zemini. 


\section{Ritmik İcra Üslubu}

Türk müziğinin temel ögelerinden olan usûl olgusu, fasıl icralarında çeșitli değișimlere uğramıș ve fasıl musikisinde müstakil bir tavır hâlini almıștır. 20. yüzyıldaki ulașılabilen kayıtlar incelendiğinde, fasıl içerisindeki ritmik yapının velvele ve süsleme ağırlıklı icra edildiği görülmektedir. Bu çalıșma bağlamında fasıl musikisi içerisinde incelenen Peșrev, Ağır Aksak ve Sengin Semai eserlerinin icralarına bakıldığında bu özgünlük daha da belirgin olmaktadır.

Gelișimi itibariyle günümüzde icra edilen fasıl musikisi -istisnai durumlar hâricinde- büyük usûllerden ayrılmıș ve bu usûllerle olan ilișiğini koparmıștır. Tanburî Cemil Bey'in 1900 tarihli bir yazısındaki ifadelerinden yola çıkarak bu konudaki tartıșmaların geçtiğimiz yüzyılın bașında da var olduğu anlașılmaktadır. Bahsi geçen yazısında Cemil Bey, büyük usûller yerine dörtlük cinsinden usûllerin kullanılması gerekliliğinden bahisle șu sözleri sarf eder (Kıyak 2017, 34-5):

"Düm, tek, tekâ, tâ hek darabât-1 müteselsile ve met'abesine uydurulmasından dolayı, makamâtımızın güzelliğine râci bir tesir-i ruhaniden bașka, sanat-1 musikiyyeye temas eder yeri olmayan büyük usûllü âsâr-1 musikiyyedeki vezn-i münharif ile, bunların dört dörtlük ile çalınırken arz ettikleri tevâzun-i tam arasında kabil-i inkâr olamayacak bir fark mevcuttur. Bir taraftan notanın kabul ve istimalini, diğer taraftan da büyük usûllerin tedavülünü istedikleri halde bunlara ait olması lazım gelen 92/4, 86/4, 126/4 gibi yalnız Avrupalılarca değil bizce de gülünç ve calib-i istihza olacağı șüphesiz olan âdâd- kesriyyeyi kullanamayacakları, binaenaleyh yine düyekten bașka bir șey olmayan dört dörtlük haricine çıkamayacakları tabiidir."

Cemil Bey'in önerdiği değișimin, Türk müziğinde büyük usûl olgusunun kaldırılmasına yönelik, bir modernleșme hareketi olduğunu söylemek mümkündür. Cemil Bey her ne kadar fasıl müziğini düșünerek bu çıkarımda bulunmamıșsa da, özellikle direklerarası fasılda Devrikebir (28/4), Fahte (20/4), Çember (24/4) gibi büyük usûllerde bestelenen peșrevlerin, Tanburî Cemil Bey'in deyimiyle "düyekten bașka bir șey olmayan dört dörtlük" Sofyan usûlü ve bu usûlün farklı șekillerde süslenmesi ile icra edilmesi söz konusudur (bkz. Nota 4).

Peșrev icralarında bir bașka önemli husus ise, mülazime ve faslın ilk sözlü eseri olan Ağır Aksak Şarkı arasındaki geçiștir. Ağır Aksak usûlü, 9 zamanlı olmakla beraber 9/8'lik Aksak usûlünün daha ağır bir mertebesidir. Fasıl icralarında kullanılan Ağır Aksak șarkılar, Nota 5'te görüldüğü gibi 2,5 zamanlı bir sus notası ile bașlar. Ancak fasıl musikisi geleneği gereği bu sus notası, peșrevin mülazimesinin son ölçüsünden bașlayan ve bağlantı sazı adı verilen melodiler bütünü ile doldurulur. Nota 4 ve 5'te görülebileceği üzere bu son ölçü, Ağır Aksak usûlüne bağlantıyı kolaylaștırmak için 3+2 șeklinde kurgulanır. Buradaki 3 vuruș Ağır Aksak usûlünün son 3 darbını, 2 vuruș ise aynı usûlün ilk 2 darbını temsil eder. Böylelikle ritmik bir yapı bozuma uğratılan peșrevin usûlü ile Ağır Aksak usûlü arasında homojen bir geçișkenlik sağlanmış olur.

İncelenen örnekler içerisinde direklerarası fasıl musikisinin bir geleneği hâlini almıș süslü ve velveleli icra tekniğinin yanında ritim ve melodik sazlar arasın- 
daki paralellik de göze çarpmaktadır. lik özelliği taşımaktadır. Ağırlıklı olarak Tıpkı bir üst başlıkta anlatıldığı gibi, 16'lık vuruşların kullanıldığı bu icrada Vasilâki'nin Kürdilihicazkâr Peșrevi'nde melodi ve ritim sazlarının vurușlarının tef sazı ile yaratılan ritmik kalıplar fasıl denkleștiği Nota 3'te açıkça görülmekicrasındaki melodik icra ile bir birlikte- tedir.
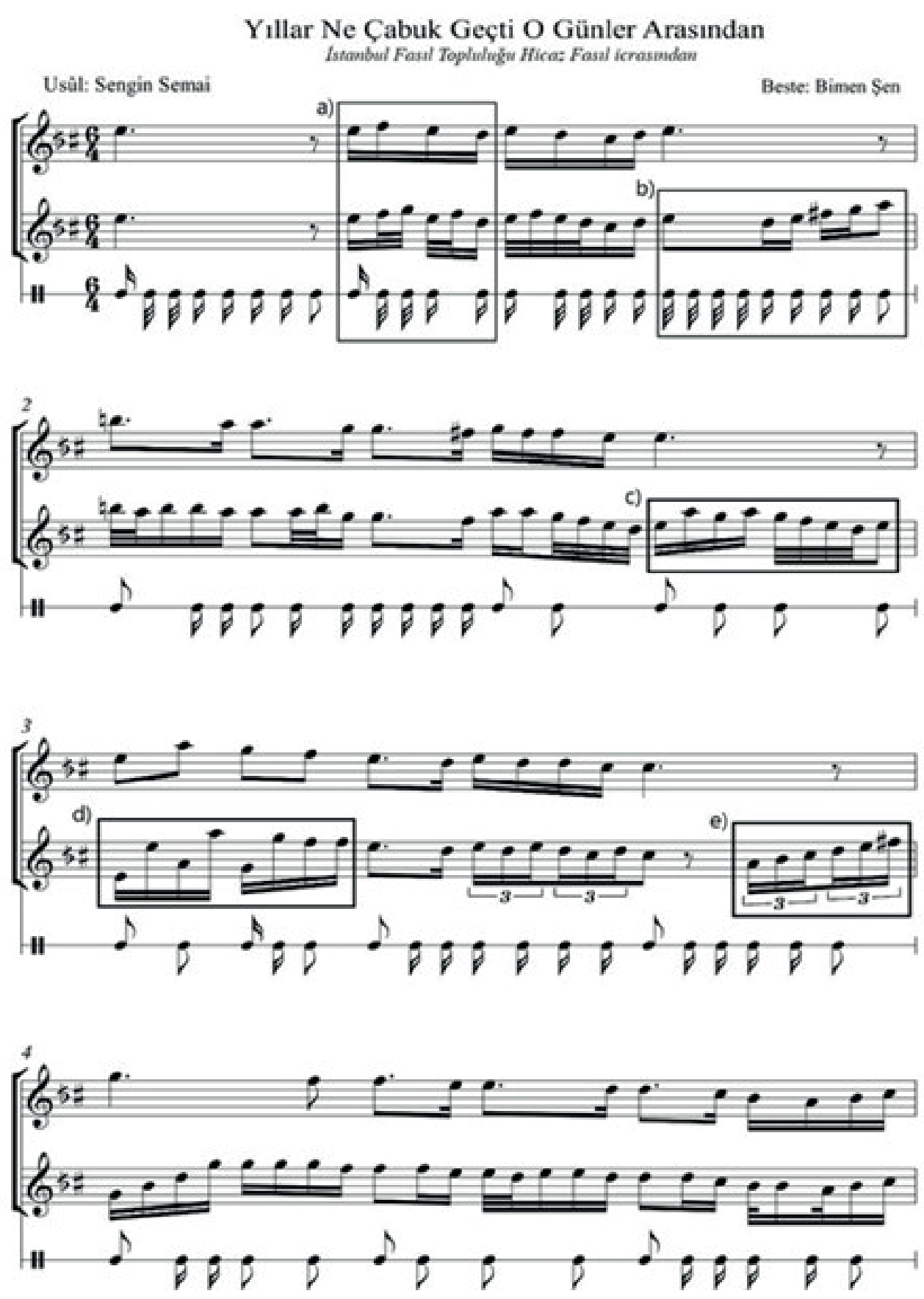

Nota 6. İstanbul Fasıl Topluluğu icrasından "Yıllar ne çabuk geçti” șarkısının nakaratı 1/2. 


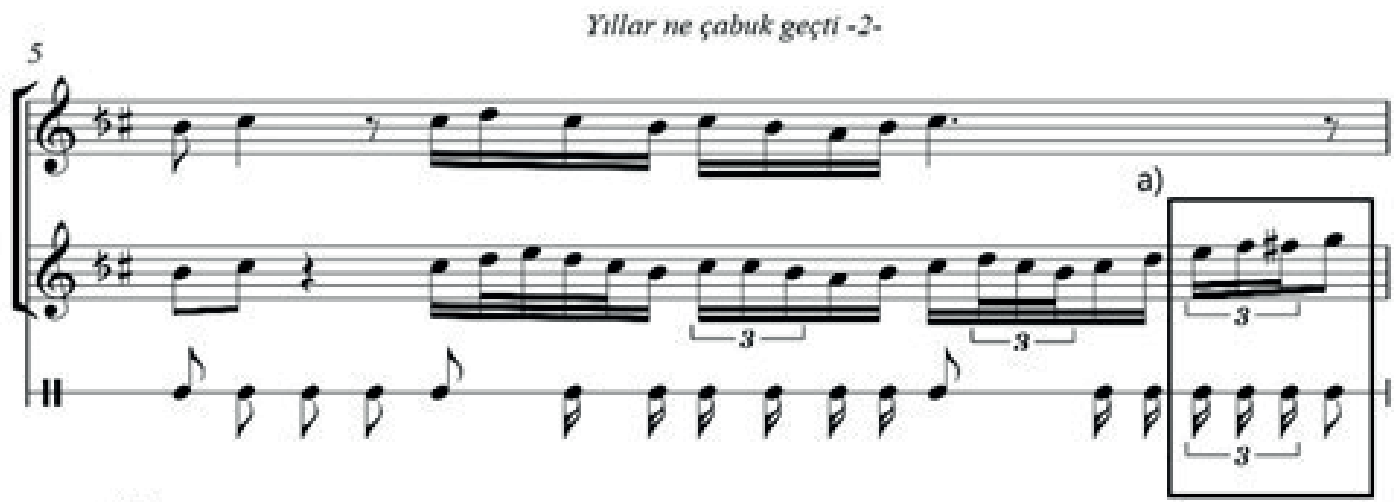

b)
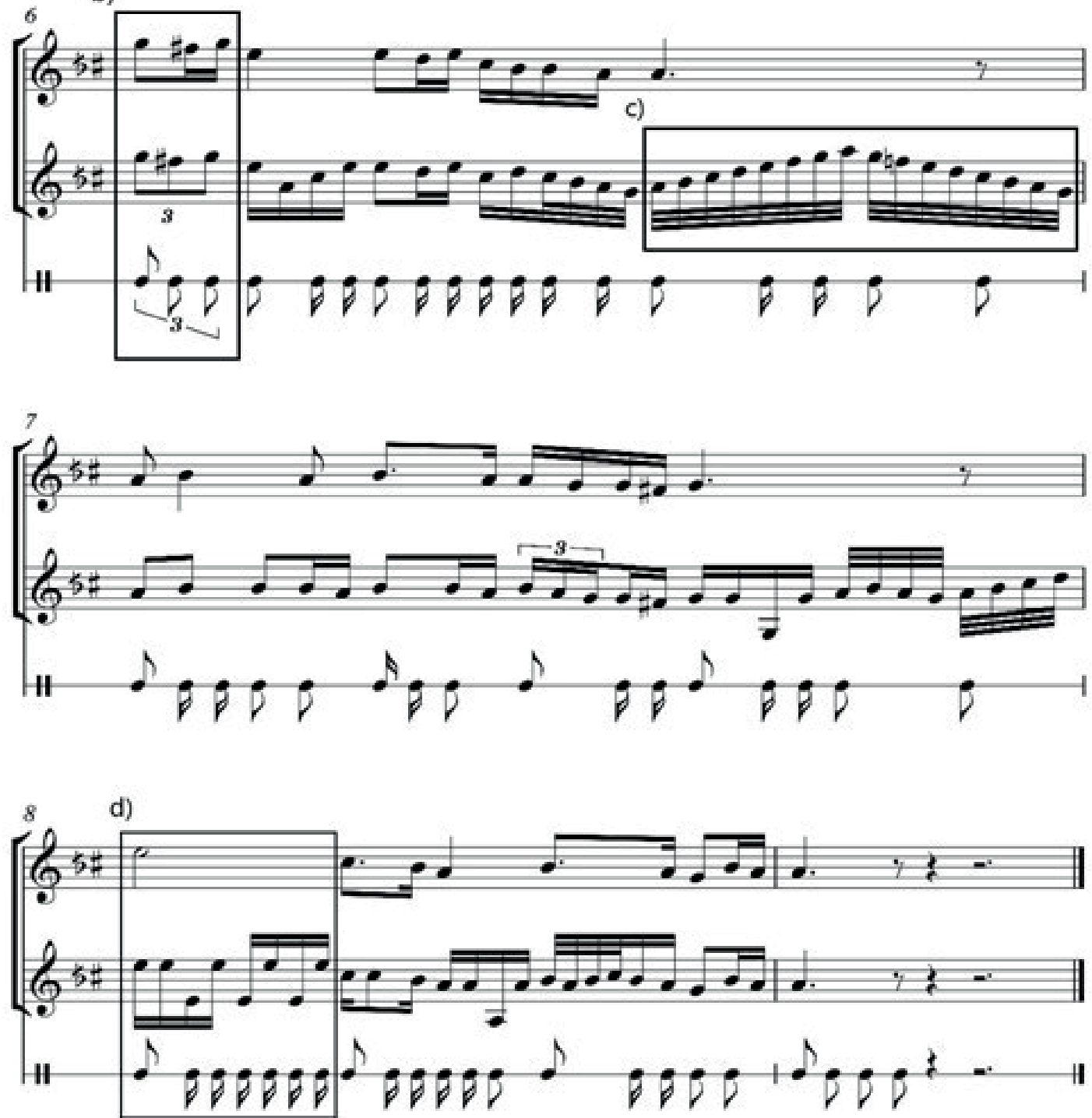

Nota 7. İstanbul Fasıl Topluluğu icrasından "Yıllar ne çabuk geçti” șarkısının nakaratı 2/2. 
İcrası itibariyle büyük usûl gibi görünen Ağır Aksak, ritim icracıları için kavranması zor bir pratik olarak karșımıza çıkar. Teoride oldukça basit gibi görünen bu usûle ait eserlerin icrası, auftaktlı girișleri sebebiyle usta icracılar arasında bir yetkinlik olarak görülür. Meșk usûlündeki aktarımında "4 Sofyan ve 1 Sengin Semai" (bkz. Şekil 1) șeklinde anlatılan bu usûl ${ }^{28}$ fasıl icracıları tarafından 8 'lik notlara bölünerek icra edilir ${ }^{29}$. Bu çalıșmanın kapsamında incelenen Ağır Aksak icrasında, usûlün kuvvetli-zayıf zamanları temel usûle sadık kalınmayarak değiștirilmiș; velvelesine de aykırı olarak, özellikle sus notalarına ve güfte hecelerinin bașlangıcına kuvvetli zaman darbı yerleștirilmiștir. Nota 5 , bölüm b ve bölüm d örneklerinde ritim çalgısı tarafından melodi sazlar ile kurulmaya çalıșılan birliktelik gerek kuvvetli zamanların denkleștirilmesi gerekse merdiven tırmanıșında aynı nota değerlerinin kullanılması ile yaratılmıștır.

Fasıl sıralamasında genellikle Ağır Aksak șarkının ardından gelen Sengin Semai usûlündeki eserlerin ritim icrasında da icracının özgünlüğü göze çarpmaktadır. Serhânende Mehmet Güntekin tarafından tef ile gerçekleștirilmiş olan Nota 6'daki örnek icrada, tıpkı yukarıda incelediğimiz Ağır Aksak icrasında olduğu gibi, usûlün kuvvetli-zayıf zamanlarının farklı kurgulandığı görülmektedir. Ayrıca ritim sazının bir serhânende tarafından icra edilmesinden kaynaklı olarak bu örnekte, güfteli bölümlerde sade bir icra anlayıșı izlenirken saz partilerinde ise bol süslü bir icra anlayıșı izlenmiștir. Ancak yine de melodi ve ritim arasında bir beraberlik kurulmaya çalıșılmış; ritim sazı, önceki örneklerde de ifade edildiği 28 Seyhun Çelik, Fasıl Ritmleri konulu görüșme, İstanbul, 21 Mayıs 2021.

29 Bkz. Nota 5, Bölüm a. gibi, melodi sazlarla aynı nota değerlerini kullanmıștır ${ }^{30}$. Nota 7'de ise bölüm a ve bölüm b'de trioleler ile, bölüm d'de ise 16 'lık değerler ile melodi ve ritim icrası arasındaki paralellik oldukça belirgin bir șekilde sağlanmıștır.

\section{Sonuç ve Öneriler}

Fasıl, icra alanı ve onu himaye edecek kurumlardan "yoksun" olan Türk müziğinin, bugünkü durumunda dahi yașayan en canlı uzuvlarından biridir. Türk müziğinin klasik döneminin (III. Selim) fasılları ile daha çok halk arasında olduğu anlașılan eğlence musikisi diyebileceğimiz direklerarası fasıla geçiş süreci oldukça önemli ve ilgi çekici bir konudur. $\mathrm{Hacl}$ Arif Bey'in bestelediği şarkılardan itibaren bu değişimi bașlatmak, bir bestecinin șahsî irâdiyla büyük değișimlere izah getirmek olası değildir. Bu șarkıların, bestelendiği cemiyette karșılık bulması, asıl peșine düșülmesi gereken meseledir. Tarihsel veriler, her ne kadar bu süreci açıkça ortaya koymaya yeterli değilse de her dönemde sosyal hayatın bir parçası olan müziğin son iki yüzyıldaki değișimini görmek için sosyal dokudaki genel değișimi takip etmek son derecede kıymetlidir.

Bir bașka așama olarak, faslın aldığı șekli; repertuar, form, ritm ve genel üslup hakkında analizler takip etmelidir. Bütün icra üslupları için notanın yalnızca bir versiyonundan yararlanıldığına göre DF söz konusu olduğunda notanın nasıl deșifre edileceği doğru aktarılmalıdır. Modern Türk müziği eğitiminde meșkin muadili olarak görülen birebir enstrüman eğitiminde, solist sazende yetiștirmekten öte fasıl icracısı olarak yetkinliğini artırmak adına çalıșmalar yapılmalı, sözlü eserler müfredata eklenmeli ve farklı tavırlarda icra ederken yapılması gerekli deșifraj

30 Bkz. Nota 5, Bölüm a ve Bölüm b. 
yöntemi öğrenciye verilmelidir. $\mathrm{Bu}$ anlamda, çalıșmamızın sınırları kapsamında örnekleri verilen fasıl analizleri gibi geleneksel aktarım silsilesinin son halkaları olan fasıl heyetlerinin bütün kayıtla$r 1$ incelenmeli, her enstrüman grubu için bu analizlerin sayısı artırılmalıdır.

Çalıșmada yapılan analizler göstermiștir ki ritim sazlardaki canlılı özellikle mızraplı enstrümanların üslubunu etkilemiştir. Yahut durağan sesleri küçük parçalara ayırmak suretiyle yapılan melodik hareketlilik, ritmin üslubuna tesir etmiștir. Çıkıș noktasından ziyade mızraplı sazlar ile perküsyon sazları arasında homojen bir unison üslubun gelișmișliği açıkça görülmektedir.

Nazariyat kitaplarında ana darp ve velvele olmak üzere iki șekilde gösterilen usûllerin çeșitliliği, müziğin yaşadığı mekânsal değişimlerin sonucunda artmıș ve darbuka ve tef gibi daha serbest icrayı mümkün kılan vurmalı çalgılar ile son raddesine ulașmıștır.

Çalıșmamızın konusunu olușturan fasıl geleneğine bakıldığında ise ritim sazların, büyük usûlleri yapı bozuma uğratarak daha velveleli, melodik ve kıvrak icralarda bulunduğu gözlenmiștir. Öyle ki 28/4, 32/4 gibi büyük usûller parçalanarak 4/4'lük Sofyan usûlüne indirgenmiş ve bu șekilde icra edilmiștir. Ayrıca iki eser arasındaki bağlantı sazlarında da bu yapı bozumun uygulandığı ve usûl ölçüsünün dışına çıkıldığı belirlenmiștir.

Yine ritim sazların bu gelenek içerisinde en belirgin özelliği, mızraplı sazlar ile sağladığı ahenk ile triole gibi Türk müziğinde melodiye özgü kabul edilen motiflerin ortaklașa kullanılıyor olduğu saptanmıştır. Mızraplı sazlar ve ritim sazların ortak nota değerlerinde bulușarak gerçekleștirdikleri icra, direklerarası faslın yapısına uygun olan bol velveleli ve kalabalık icrayı görünür hâle getirmiș, bu geleneğin olmazsa olmaz bir parçası olmuștur. 


\section{Yazarların Biyografileri}

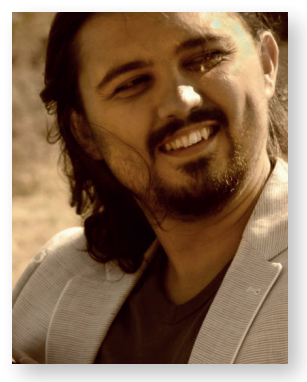

\section{Bekir Şahin Baloğlu}

1985 yılında Kayseri'de doğdu. Amatör olarak bağlamayla meșgul olan babası Osman Baloğlu'ndan musiki zevki terennüm etti. Illk ciddi musiki eğitimi Kayseri'de İsmail Ediz'den aldığı ud, nota ve nazariyat dersleriyle başladı (1996). Kayseri Anadolu Güzel Sanatlar Lisesi'ni (2003) ardından iTü Türk Musikisi Devlet Konservatuarını bitirdi (2008). Aynı üniversitede yüksek lisans eğitimini (2014) [Dinî Türk Müziği Beste Türlerinden Durak], Marmara Üniversitesi İslam Tarihi ve Sanatları alanında doktorasını tamamladı (2020) [Osmanlı Müzik Yașamının Değişim Sürecinde Gelenek İcadı ve Artistik İcranın Temsilcisi Olarak Tanburî Cemil Bey]. Müzik anlayıșının olgunlașmasında Mahmut Nedim Aysoy, İsmail Ediz, Ali Atay, Ahmet Tolga Özdemir, Mehmet Bitmez, Fahrettin Çimenli, ş. Ünal Ensari gibi isimlerle yaptığı meșkler etkili oldu. Halen müzik çalıșmalarına devam etmekte, Perdesiz Bağımsız Türk Müziği Dergisinde yazılar yazmakta Yıldız Teknik Üniversitesi Sanat ve Tasarım Fakültesi'nde öğretim görevlisi olarak görev yapmaktadır.

Tel: +90 5303633187

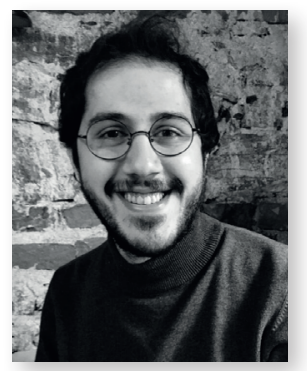

\section{Bedirhan Büyükduman}

1993 yılında İstanbul'da doğdu. Lisans eğitimini 2016 yılında ìstanbul Üniversitesi Illetișim Fakültesi Gazetecilik Bölümü’nde tamamladı. 2020 yılında Yıldız Teknik Üniversitesi Müzik ve Sahne Sanatları Bölümü’nde yüksek lisans eğitimini tamamladı. Șu anda yine aynı kurumda doktarasına devam etmekte ve İstanbul Sabahattin Zaim Üniversitesi Müzik Öğretmenliği Bölümü'nde araștırma görevlisi olarak görev yapmaktadır.

Küçük yașta TRT İstanbul Radyosu Saz Sanatçıları Kanunî Șener Altınbaș ve Udî Caner Altınbaș ile müzik eğitimi ve çalıșmalarına başladı. 2009 yılında yine TRT İstanbul Radyosu Saz Sanatçısı Seyhun Çelik ile perküsyon çalıșmalarına bașladı. Mustafa Doğan Dikmen yönetimindeki TRT İstanbul Radyosu Türk Sanat Müziği Gençlik Korosu'nda (2016-... ), N. Özgül Turgay yönetiminde YTÜ Cumhuriyet Korosu'nda (2018-2020), Elif Ahıs yönetimindeki Üniversite Korosu'nda (2018-...) perküsyonist olarak çalıșmaya başladı ve konserlere eșlik etti. Birçok üniversite kurulușunun projelerinde perküsyonist olarak yer aldı.

Tel: +90 5312653165 


\section{Kaynakça}

Büyükduman, Bedirhan. 2020. “Demokrat Parti Döneminde Uygulanan Kültür Politikalarının Türk Makam Müziğine Yansımaları”. Yayınlanmamıș Yüksek Lisans Tezi. Yıldız Teknik Üniversitesi Sosyal Bilimler Enstitüsü.

Çelik, Seyhun. 21.05.2021. "Fasıl Ritimleri konulu görüșme".

Çokuğraș, Ișıl. 2016. Bekâr Odaları ve Meyhaneler: Osmanlı İstanbulu'nda Marjinalite ve Mekân. İstanbul: İstanbul Araștırmaları Enstitüsü Yayınları.

Mimaroğlu, Reșad. 1971. "Fevziye Kıraathanesi”. İstanbul Ansiklopedisi: 5727.

Öncel, Mehmet. 2010. “Rauf Yektâ Bey'in Ati, Yeni Mecmûa, Resimli Kitap ve Șehbâl Adlı Mecmûalarda Mûsikî ile İlgili Makalelerinin İncelenmesi”. Yayınlanmamış Yüksek Lisans Tezi. Marmara Üniversitesi SBE.

Özpekel, Osman Nuri. 2014. "Türk Mûsıkîsinde Fasıl ve İcra”. Yeni Türkiye (57).

Pekin, Ersu. 2015. “'̇stanbul'un Sesleri: Osmanlı Döneminde İstanbul'daki Müzikler". İstanbul Büyük Șehir Belediyesi Kültür a.ș Yayınları: 55.

Popescu-Judetz, Eugenia. 1999. “Osmanlı'da Fasıl". Osmanlı 10.

Tosun, Bekir. 1994. “Direklerarası”. DiA.

Turan, Namık Sinan. 2016b. "Osmanlı Barok Çağının Șairi Nedim ve Değișen Zihniyet Dünyası". Evrensel Kültür Aylık Kültür ve Edebiyat Dergisi (296).
2017. Yüz Yıllık Metinlerle Tanburi Cemil Bey. Haz. Hüseyin Kıyak. İstanbul: Kubbealtı Neșriyat.

Zat, Vefa. 1971. "Gazinolar". Dünden Bugüne İstanbul: 379.

Elektronik Kaynaklar

Gürses, Kemal. 1994 Kürdilihicazkar Peșrevi - Kürdilihicazkar Fasl, Uluçınar Müzik. https://open.spotify.com/track/3TVSog8EdjYL1LymDDpaqU.

Hicaz - İstanbul Fasıl Topluluğu - TURING - 16.04.2019. TURING KÜLTÜR SANAT. https: //youtu.be/s7jtEZiT28Y?t=937, erişim tarihi: 24.11.2020

Kızılay, Ergin. 1993. Hüzzam Peșrevi - Süper Fasıl Vol. 2. Kalite Ticaret Plak. https://open.spotify.com/track/14zRD8SjpzMSRu6CNrWMnX?si=B4PTkXQyQACdLAYTs1yOow

Körükçü, Nesrin. 2013. Yıllar ne çabuk geçti o günler arasından - Bir Şarkıdır Yașamak Box Set. Bonus Müzik Prod. https://open.spotify.com/ track/4Kw20WvCD6jzektO2oDnNf

Mesud Cemil. 2000. Kürdilihicazkar Peșrevi. Mesut Cemil (1902-1962) Volume I. Golden Horn Productions. https: //open. spotify.com/track/400cHfTRnBw0gzlhP$\mathrm{Km} 9 \mathrm{LH}$ ?si=3f308684616c4f06

Utandı, Münip. 1995. Yıllar ne çabuk geçti - Aynalıkavak'tan Kalamıș’a. Kalan Müzik. https://open.spotify.com/track/4BRQHAtQH9l8OEFKdwhBld 


\section{Transformation in the history of the fasıl and the accompaniment traditions in direklerarası fasıl}

\section{Extended Abstract}

One of the Turkish music performance traditions from the last times of the Ottoman Empire to the present, "fasıl" constitutes a special place. In addition to the special meaning of performing several pieces in the same maqam with a specific sequence from slow to moving, fasil has also been used to explain any musical performance and has a broad meaning. The differences between the "classical fasil" that appeared at the beginning of the nineteenth century and the "direklerarasi fasil" at the end of the same century, in terms of content and presentation necessitates an explanation of this dramatic transformation in the light of the data. The repertoire, the performers, and the performance style formed in this culture are far from the simplicity dictated by the European notation, which has been widely used for the last hundred years. It is clear that the style with velvele of rhythm instruments used in the fasil have a relationship with the additional notes made by the plectrum instruments in long sounds. In this study, the historical traces of the transformation in fasil styles will be traced, and the effects of plectrum and rhythm instruments on fasil music in the direklerarası fasil tradition will be examined.

In this study, in which the data analysis method, one of the qualitative research methods, is used, the transition from the classical fasil to the direklerarası fasil is explained by associating it with political changes. Because, with the modernism that gradually took over the social life, in the last century of the Ottoman Empire, daily life became active, and partnerships were seen between the palace bureaucrats and the city as never before. The traces of the common musical taste in the last period of the Ottoman Empire were traced in the memories of the performers and the audience in places such as coffee houses, taverns, and casinos, and information about the repertoires and performers of direklerarası fasil after the Republic was given. To show the direklerarası fasıl style, four different pieces, which are definitely used in fasil repertoires, have been analyzed on musical notes. Two of them are "Peșrev" in "Ağır Düyek" and "Devr-i Kebir"; the other two are songs in the "Ağır Aksak" and "Sengin Semâi" styles. Performance samples were selected from the performances of three different musical groups. The analyzes are shown on the note with the original score of the piece, the additions of the plectrums, and the velvele of the percussion instruments in three separate parts. As a result, it has been understood that despite the changes in the political conjuncture that affects the functioning of music, the tradition of direklerarası fasıl still continues. Today, instrumentalists are widely trained to become soloists. However, for the continuation of the direklerarası fasil tradition, which continues to come to life by chance in the modern world, the ornamental forms created by the fasil style should be utilized to the maximum extent in instrument education. The unity of rhythm and plectrum instruments should also be dictated during the education process.

Keywords: fasil, difference of interpretation and note, plectrum duate, accompany, ağır aksak 